\title{
SEVEN FUNDAMENTAL ECONOMIC CHARACTERISTICS EXCLUSIVITY OF AGRIFOOD SUPPLY CHAINS
}

\author{
(part 1)
}

This analysis focuses on defining and describing the unique economic characteristics of agrifood supply chains. The analysis includes seven specific economic characteristics of agrifood supply chains that distinguish them from other industrial manufacturing and service supply chains. The seven characteristics are: 1) risk emanating from the biological nature of agrifood supply chains, 2) the role of buffer stocks within the supply chain, 3) the scientific foundation of innovation in production agriculture having shifted from chemistry to biology, 4) cyberspace and information technology influence on agrifood supply chains, 5) the prevalent market structure at the farm gate remains oligopsony, 6) relative market power shifts in agrifood supply chains away from food manufacturers downstream to food retailers, and 7) globalization of agriculture and agrifood supply chains.

Keywords: agrifood supply chains, exclusive economic characteristics, risk, market power, globalization

\section{Exclusivity of Agrifood Supply Chains: Seven Fundamental Economic Characteristics}

Are there meaningful economic characteristics that serve to make some supply chains unique and different from others? This analysis identifies and describes seven fundamental economic characteristics of agrifood supply chains that serve to distinguish them from other supply chains in the manufacturing and service sectors of the economy. The focus here is on the uniqueness of agrifood supply chains in terms of their economic character. This uniqueness has powerful implications for managers within agrifood supply chain firms and the long-term strategies that they might craft to enhance the long-term performance of their firm.

The complexity and length of agrifood supply chains serve to distinguish them from manufacturing and service sector supply chains. One example of complexity is the perishability of commodities and postharvest technology, such as hydrocooling sweet corn, that is used to assure quality and safety from the field to a processing facility or directly to a downstream consumer of a fresh product. Evidence of these complexities exclusive to agrifood supply chains is plentiful. For example, food chain management books are available which provide best practices for managing temperature controlled supply chains [22]. Adding to the length of these complex agrifood supply chains is the long-term trend toward globalization where large-scale commercial operations, located and coordinated on an international basis, produce and process food sited globally to minimize costs.

Seven unique economic characteristics of agrifood supply chains are defined and described. The meaning, context, and consequences of each characteristic are discussed in some detail. Each characteristic serves to differentiate agrifood supply chains from manufacturing, service, and nonagricultural manufacturing supply chains.

The seven characteristics are: 1) risk emanating from the biological nature of agrifood supply chains, 2) the role of buffer stocks within the supply chain, 3) the scientific foundation of innovation in production agriculture having shifted from chemistry to biology, 4) cyberspace and information technology influences on agrifood supply chains, 5) the prevalent market structure at the farm gate remains oligopsony, 6) relative market power shifts in agrifood supply chains away from food manufacturers downstream to food retailers, and 7) globalization of agriculture and agrifood supply chains. Each of these economic characteristics is examined and implications for agrifood form managers are provided. 


\section{Risk Emanating from the Biological Nature of Agrifood Supply Chains}

Unlike other industries where manufacturing takes place in controlled and closed-loop environments, agrifood production faces high yield risk both in terms of quantity produced and quality delivered. Production agriculture is different from numerous industries because of the supply risk due to weather, biological aspects of production cycles, and perishability. Risk is pervasive for all parties in the agrifood supply chain. The biological nature of agricultural production results in less predictable supplies of various grades or characteristics compared to manufacturing and service sector supply chains. Prices are meaningful in their allocative role within supply chains if and only if they relate to products of identified homogeneous quality. In the case of agrifood supply chains, this entails grading systems that are accepted and used by most supply chain participants for a particular commodity. ${ }^{1}$

Quantity risk is the temporal shortfall in supply, embedded in the biological nature of agricultural production (e. g., cows freshening, trees not bearing fruit, pest infestations in fruits and vegetables, etc.) to shortfall from weather vagaries or other unforeseen calamities. These issues impact supply and result in short-run or seasonal limits on available quantities to the market. Such haphazard supply limits are unanticipated and are not systematic. Numerous examples exist in the literature that highlights such phenomenon, including apples (Boland, Mancia, and Taylor 2010) and oranges [21]. Beddow, Pardey, and Alston [2] examine global variability in crop yields over the 1900 to 2006 time period and find that maize has the largest increase in productivity, measured by average crop yield increases relative to soybeans, wheat, and rice since 1960 . Volatility in yields also has been the greatest in maize. This has an obvious impact on profitability of agrifood firms. Crop yields have greater uncertainty relative to milk or meat yields from animals due to greater unforeseen or unanticipated events.

Price risk is the fluctuating prices from changes in supply and demand. The typical methods for managing this type of risk are hedging in the futures market or entering into a fixed-price contract that often specify delivery quantities and quality attributes. For example, an examination of

\footnotetext{
1 The broadest authorization for commodity grading systems in the United States is provided by the 1946 Agricultural Marketing Act, although commodities such as cotton, grain and tobacco also have their individual authorizations. The United States Department of Agriculture has a long history of involvement with commodity grades and standards.
}

the contracts available on the Chicago Mercantile Exchange reveals that agricultural commodities are one of nine inputs that have futures contracts available for use by buyers. Others include metals, interest rates, exchange rates, energy and weather. Index funds are one of the largest traded futures but food commodity futures, although smaller volume, are essential for use by agrifood processors and producers in managing price risk. The Food and Agriculture Organization (2011) provides monthly price indices for food, meat, dairy, cereals, oils, and sugar. An examination of the 1990 to 2011 data shows substantial volatility since 2004 relative to the preceding years. This has an impact on agrifood firm profitability. The relative impact on profitability depends upon where the agrifood firm is embedded in the value chain. Upstream firms closer to production experience greater variability in profitability relative to those downstream firms closer to consumers.

Quality risk refers to the specific qualities or grades of a commodity or a product that are necessary as an input but that may not be available at a certain time. Various qualities or grades of a commodity are not fungible across processors, often because the complement of equipment in a processing line dictates use of a narrow range of existing commodity qualities. One example is a cotton mill processing line that is equipped to use only long staple cotton. In this instance, short staple cotton is not fungible for long staple [11]. A similar example is processing tomatoes [10]. A specific complement of machinery within a processing plant may influence the range of qualities or grades that can be an acceptable input in the production process.

Commodity characteristics include perishability and seasonality in production and/or consumption. Examples include fresh fruits and vegetables, fluid milk, and some meat animal production. Substantial price swings within a marketing season can result for commodities with these characteristics (Breimyer [4]; Rhodes, Dauve, and Parcell 2006). For example, price typically is lowest at the end of harvest and gradually begins to rise as supply begins to decrease (e.g., inventories are lowered) until the new marketing season begins. For crops in the northern hemisphere, the marketing year is generally September of the current year until August of the following year, except for summer crops such as hard red or hard white winter wheat.

Increases in global distribution channels have eliminated some of this seasonality, especially in horticulture production. Historically, fresh fruits and vegetables were available only during certain times of the year within season. Globalization 
has resulted in supplies now available year- round and, consequently, seasonal price variability is dampened, except for seasonal quantity or quality issues such as supplies damaged from frost or disease. This price effect, at least partially, is attributable to the biological nature of agricultural production. Adjustments in aggregate with- in-season supply through private or public inventory adjustments typically are not feasible for perishable commodities. In some instances, the biological nature of production involves longer periods spanning several years, as is the case with perennial tree crops such as almonds, which could lead to wide price swings across seasons (Boland, Pena, and Sumner 2010).

Perishability and production seasonality give rise to the concept of orderly marketing. The foundation of orderly marketing includes concepts of supply and demand levels, price levels and price variability over both time and space. The term 'orderly marketing' for a commodity means an orderly flow of the supply to market throughout the normal marketing season to avoid unreasonable fluctuations in supplies and prices as stated in Section 2(4) of the Agricultural Marketing Agreements Act of 1937. In U.S. legislation, orderly implies dampened within-season price variability compared to the price variability that might occur if the commodity were marketed in an unregulated purely competitive open spot market. An example of this is raisins which are governed by the Raisin Administrative Committee [19].

Seasonality in production and marketing has played an important role in the development of United States marketing policies in milk, fruits, and vegetables. Orderly marketing appears as the central component in some marketing order policies (Black 1947). For example, milk marketing orders have an explicit orderly marketing legal mandate that underlies their promulgation and provisions. Assurance of adequate supply is a portion of the economic foundation which means having a continual supply available to consumers. In this instance, accuracy is rooted in the notion of perfectly competitive market structures where price differences over space reflect only differences in transportation costs through spatial arbitrage and that, within a geographic market area, prices are identical for the same quality to all buyers and all sellers. This is often referred to as von Thunen's model (1966). Similarly, price differences among qualities within a market are sufficient to provide accurate signals to sellers on the relative value of various qualities.

Yet another risk of agrifood supply chains participants is adulteration, a separate issue from the temporally-based quality issues discussed above. Risk of unsafe food is the risk that input supplies are substandard or adulterated, as one aspect of this risk type. This risk relates to the use of unsafe food or input supplies, regardless of whether the usage was intentional (i.e., using substandard or adulterated products) or unintentional (i.e., mistake or insufficient knowledge). This risk is typically unintentional yet supply chain interdependencies link multiple downstream participants to any one particular food safety incident. A fear of food manufacturing firm managers is that the products they distribute are unsafe and they then must issue an expensive recall (Sporleder and Goldsmith 2001). This risk can be financially devastating to a firm due to the cost burden of a recall or the diminished reputation of the firm or its brands that may result from a recall. Adulterated product, leading to recalls, is a systemic risk for the entire agrifood supply chain. Hudson Foods is one example of how devastating recalls can be for an individual firm. Hudson Foods is no longer in business because of their recall of hamburger.

There are no shortages of adulteration incidents. Recent examples in the United States abound: 1) dog food ingredients, imported from China, contained toxins that resulted in dogs becoming ill [18]; 2) contaminated peanut butter paste from a food manufacturing firm in Georgia that resulted in several deaths in the United States [26], 3) fresh spinach that was widely distributed but contained food borne pathogens [17], and 4) Colorado cantaloupe recall of 2011 due to Listeria which was the largest recall in U.S. history. Agrifood supply chains are unique in the United States because they are regulated by four federal agencies: the Animal and Plant Health Inspection Service (APHIS) of the U.S. Department of Agriculture, the Food and Drug Administration (FDA), the Environmental Protection Agency (EPA), and the National Oceanic and Atmospheric Administration (NOAA) of the U.S. Department of Commerce. The agrifood sector is unique, compared with industrial sectors, in terms of federal regulations for product and process regarding the environment, plant and animal products, and processed food products.

\section{The Role of Buffer Stocks with the Supply Chain}

In the case of nonperishable (storable) commodities, such as wheat, cotton, and corn, the stocks in storage buffer intra-seasonal and inter-seasonal price movements (Breimyer 1976). Nevertheless, perishability precludes this buffering or moderating influence on within-season 
price of carryover stocks from one period to the next. This is why inventories of storable commodities, such as wheat and corn, are often referred to as buffer stocks. In addition, inventory stocks can buffer against the quantity and quality risks discussed above.

When a commodity is perishable, such as fluid milk, buffer stocks are not feasible. In these cases, contracts tend to replace spot market transactions and buffer stocks (Sporleder 1992; Mac- Donald and Korb 2011). In most conventional industrial supply chains, privately-held buffer stocks are a common means of hedging quality, quantity, and price risks by manufacturing firms in the supply chain. For example, if a supplier cannot make a just-in-time delivery of an input, the manufacturer may draw down buffer stock inventory to keep production lines operating in a normal manner.

For less-perishable commodities, storage helps achieve vertical coordination in the supply chain (Working 1949; Breimyer 1976 [4]). Buffer stocks are held by private firms in upstream and downstream markets in an effort to mitigate quantity and quality risk and generally deal with unexpected events. For perishable commodities buffer stocks are neither practical nor cost effective. One consequence of these phenomena is that the supply chain coordination problem is more severe and alternative exchange mechanisms emerge beyond simple spot market transactions. Contracting is an important mechanism that substitutes for privately-held buffer stocks in terms of providing a similar economic function [16].

Contracting of perishable commodities can be a means of enhancing supply chain coordination and act as a surrogate for the economic role of privately-held buffer stocks that are prevalent among storable commodity supply chain participants. Contracts facilitate the contractor who is typically the downstream first-handler/processor to specify the quality and quantity that can be delivered under the terms of the contract. The contract may even be a fixed-price contract. These possible features of a contract mitigate the quality, quantity, and price risk discussed above, thus substituting for the economic role played by buffer stocks in storable commodities. Such contracts might be linked to publicly reported price data such as the Agricultural Marketing Service of the U.S. Department of Agriculture, Milling and Baking News, Feedstuffs, or the Food Institute Report which are widely used as a starting point for some price negotiations. James, Klein, and Sykuta [12] and Dorsey and Boland [6] synthesize numerous examples for agrifood firms.

\section{The Scientific Foundation of Innovation in Production Agriculture has Shifted from Chemistry to Biology}

Three eras of agriculture relative to innovation are worth noting [9]. The first era is mechanical where the most significant innovations were based on mechanization of all kinds. This era is noted for tractor power replacing horse power; in general, the substitution of capital for labor. In the United States, this era faded in the 1950s to be replaced by the chemical era. The chemical era is marked by substantial gains in efficiency through various applications of chemistry, such as chemical fertilizers, pesticides, and antibiotics for farm animals that facilitated production practices such as large-scale confinement feeding. The third and present era is agricultural biotechnology.

The fundamental science for innovation in agricultural production has shifted rather quickly from chemistry to biology [5]. The advent of commercial biotechnology influencing agricultural industries is rooted in the 1970's. Chandler (p.10) notes that «... by the 1970's, chemical science and engineering was no longer generating significant new learning, whereas at the same time biology and related disciplines, especially molecular genetics, witnessed an explosion of new research and insights. Based on this new learning, chemical and pharmaceutical companies built new integrated learning bases, erected new barriers to entry, and defined new strategic boundaries.» For example, DuPont, even though its roots were firmly in chemistry, remade itself into a company whose research and development is predominantly based on the science of biology, beginning its transformation in the mid-1980s.

The advent of the first genetically engineered crops available to farmers as a result of agricultural biotechnology was in mid-1990. For example, genetically-modified soybeans and corn were widely available for the 1996 crop year, even though some genetically-modified seed was available the previous crop year. The fundamental change from chemistry to biology as the primary source for innovation provided opportunities, as never before, to accelerate food product innovation and open the potential for food to play an expanded role as a delivery mechanism for medical technology.

The expanded role as a delivery mechanism for medicine is in addition to the traditional role of human sustenance from caloric intake [7]. Historically the purpose of food consumption was sustenance through ingesting calories and nutrients $[24 ; 23]$. After that need was met, taste became important in preferences [13]. More recently, 
convenience is one determinant of consumer food preferences (Boland 2010).

Today's modern consumers now ask for more. In addition to nutrients, taste and convenience, some consumers now consider personal health. These attributes are based on a sense of food safety and a longer-term attribute in the form of functional foods and nutraceuticals [14]. As obesity has become an epidemic brought on by lifestyle choices and convenient but high-caloric food products, personal health attributes for many consumers already have become an important added bundle of expectations for their foodstuffs.

The shift from chemistry to biology as a source of innovation in agrifood supply chains has made biology the science of tomorrow. Biology, through genetics, is about information storage, duplication and transfer involving the most sophisticated devices ever imagined. Indeed, the transformation is so dramatic that synbiology synthetic biology now captures an emerging area of synthetic biology. Synbiology is the engineering of biological components and systems that do not exist in nature and the re-engineering of existing biological elements. Synbiology is determined on the intentional design of artificial biological systems, rather than on the understanding of natural biology. Synbiology aims at the design of artificially modified living systems, such as specialized cells for biosensing and biobased and highly controlled synthesis, or for high yield production of biological molecules for in vivo or in vitro use. Synbiology is determined on the intentional design of artificial biological systems, rather than on the understanding of natural biology (European Commission FP6 2005). This emerging area promises to construct new bio- functional systems to build novel proteins, genetic circuits and metabolic networks based on knowledge contributions from biology, engineering, mathematics, and physics.

Molecular genetics and synthetic biology will impact preventive and curative medicine at an accelerated pace as well as find applications in the food supply (University of Idaho 2010). For example, nanoparticles may be used to target certain genes and therefore aid in genetic engineering of food animals. In another application, nanomaterials might enhance the shelf stability of food products and help assure their safety. Nanotechnology allows integration of biology and information technology through nanoscale approaches that will find direct application in human medicine. For instance, DNA markers alert individuals through adapted information and communication systems to any alteration of the biological infor- mation system. Blood pressure and quality will be monitored real-time and continuously via biosensors. Biosensors also are increasingly employed in food science to detect pathogens without disrupting food processing or product flow.

The advent of personalized or individualized medicine, made possible by rapid and fundamental advances in biology, portends the day when prediction of future patient maladies is likely. The change is that medicine evolves from treatment of a condition after it is diagnosed to current active management so that the future condition is delayed, minimized, and/or avoided completely. This model for medical treatment is an evolutionary shift from reactive to proactive. The consequent change for the agrifood system is that food and even obligatory preventive diets may become commonplace. One prospect is that food and diet become a means of delivering customized medical knowledge to patients.

There are major implications of this evolution to food as a delivery platform for medical and biotechnology intellectual property. ${ }^{1}$ One potential is for the proliferation of numerous small specialized niche markets for foods (Sporleder, Goldsmith, and Cordier 2008). Another example is probiotics in numerous foods [20]. Rapid biotechnological advance will continue to blur the lines between food and medicine. Enhanced demand for nutraceuticals and functional foods results.

\section{Cyberspace and Information Technology Influences on Agrifood Supply Chains}

Cyberspace and information technology changes everything from business models to how feasible outsourcing is as a strategy for firms that operate in global agrifood supply chains.

The present and future are described as the Age of Knowledge because science and technol-

\footnotetext{
${ }^{1}$ Sussex (2008) provides informative statistics on the evolution of agricultural biotechnology and how rapidly it developed globally. Sussex indicates that the first transgenic food crop to be commercialized was FlavrSavr, a delayed ripening tomato, in 1994. By 2006 transgenic crops were planted on 102 million hectares ( 252 million acres) in 22 countries ( 11 industrial countries and 11 developing countries) by 10.3 million farmers: 9.3 million of these farmers were resource-poor with small farms in developing countries. Soybean was the principal transgenic crop in 2006, occupying 58.6 million hectares, followed by maize ( 25.2 million hectares), cotton (13.4 million hectares), and canola (4.8 million hectares). The first field trials of transgenic crops were conducted in 1986 to test herbicide tolerance in tobacco. By 2005 nearly 3500 field trials had been conducted at more than 15,000 sites in 34 countries on 56 crop species. The eight most frequently tested species were maize, canola, potato, tomato, tobacco, soybean, cotton, and melon. In 2007, it was estimated that 140 species of angiosperms had been genetically transformed.
} 
ogy are integrated for increasing productivity and consumer value. The Age of Knowledge enhances the well-being of citizens and enhances the average global living standard (Federal Reserve Bank of Dallas [8]). Knowledge formation is increasing at increasing speeds to address the rapid development, shifts, and expansion of consumer demand.

Transportation and communication technology have allowed efficiency gains since the 1970's, cutting real ad valorem freight rates by more than 40 percent. The widening of the Panama Canal, slated for completion in 2014, will offer greater efficiencies for the eastern U.S. seaports. Goods are now moving around the world, not only at low cost but with containerized and parcel shipping from producer to final consumer using customized contracts or private third-party services. More recently, digital communications not only significantly decreased the average costs of exchanging information, but allows knowledge transfer at near-zero marginal cost and without practical limits to speed. As a consequence, the supply of information in knowledge products is not limited, allowing increases in the quantity demanded without necessarily a rise in price.

Transactions in agrifood supply chains tend to be complex and often supply chain segments involve perishability, both in terms of spoilage and time-related degradation of product quality (Pritchett 2004). Information technology provides a foundation for cost effective just-in-time deliveries, enhanced ordering capacities, and facilitates traceback and identity preservation so that food recalls become more effective and efficient. It enables higher quality supply chain transactions at lower costs [1].

There are two substantial direct impacts of information technology. First, processors can use economic incentives through production or marketing contracts to induce producers to grow a certain plant variety or animal breed that has some desired quality characteristic. For example, certain soybean varieties have lower levels of oil that yield a lower saturated fat (Sykuta and Parcell 2003). Certain animal breeds have less external or internal fat and processors can contract for such breeds (Roe, Sporleder and Belleville 2004). Second, processors can utilize current commodities and use research and development to remove the saturated fat or reduce the number of calories in a food as a response to economic incentives from consumers. The cost of doing so may be less than trying to acquire the seed germplasm, modify the genetics, and contract with producers to produce the plant. Many crops have potential for such differentiation. For example, Boland's (2001)
Economic Issues Series summarizes the potential for value-enhancement in various crops provided in 15 different publications.

A large but relatively unnoticed part of information technology has been the harmonization of information used in business transactions between firms in different countries. For example, in 2002 the United States, Canada, and Mexico began using the North American Industrial Classification System. This system harmonizes industry definitions across international borders and makes data more meaningful and easier to use. In 2011, international accounting standards to report firm-level financial information emerged (International Financial Reporting System 2011). The adoption of the metric system in many countries has helped standardize weights and other measures globally. Veterinary and other scientific protocols are becoming more standardized across countries, which enhance trade (Marshall, Boland, and Conforte 2002). International Organization for Standardization (ISO) has developed similar standards for best organizational practices. In addition, the data collected on prices, volumes of imports and exports, and similar data is becoming harmonized across countries. All these efforts have resulted in better data for business intelligence and research purposes.

The ability to trace a food product back to its origin is becoming less complex due to information technology. This is useful because as food safety standards increase and trade becomes more prevalent, the need to rapidly respond to a potential food illness or product safety recall will become more important (Kinsey et al. 2009). Furthermore, as some countries adopt country-of- origin labeling in certain foods, the need for information technology becomes more necessary. Although information technology has imposed a cost on firms through regulatory compliance (e.g., food safety and/or reporting), it may reduce costs through the ability to better match consumer or societal demand for better nutrition or similar goals. Thus, information technology has become an important competency for agribusiness firms that can adopt global standards quickly (Bailey, Jones, and Dickinson 2002). Information technology facilitates building interfirm social capital and vertical ties of many kinds (Sporleder and Wu 2006).

\section{Prevalent Market Structure at the Farm Gate is Oligopsony}

For many agricultural commodities, the market power of sellers (farmers) and buyers (processors or other first-handlers) is unequal, with substantial market power enjoyed by buyers (Marion and 
Sporleder 1976; Marion and Kim 1991; Rogers and Sexton 1994). There is a great deal of evidence that suggests that food manufacturing exhibits characteristics of monopolistic competition (Boland et al. 2012). In the United States, this fundamental characteristic has resulted in substantial legislation and rule-making by various governmental agencies that are intended to redress the balance of market power or protect farmers from experiencing the full force of unequal market power.

In the United States, the 1920s and 1930s were decades of concern over the market power of first-handlers and buyers of farm products. This concern resulted in legislation intended to countervail oligopsonistic market power at the producer-first handler level in the agrifood supply chain. Legislation stemming from countervailing power concerns encouraged the formation of farmer cooperative organizations and a myriad of regulatory tools that allowed producers to work together on common marketing issues. Examples include the Capper Volstead Act of 1922 and marketing orders covering several agricultural commodities. While some of the fruit and vegetable marketing orders initially had provisions designed to suppress short-term supplies, these provisions were largely eliminated in the 1970s. The annual U.S. Department of Agriculture Rural Business Service's Cooperative 100 profile indicates that aggregate agricultural cooperative market share has been increasing over time in many industries (e.g., fluid milk, feed).

In the United States, the set of antitrust policies which bears directly on economic power at the producer-first handler level begins with the Sherman Antitrust Act of 1890 and continues through the 1970s with additional interpretations of Capper-Volstead from a rather complex set of case law. The Capper-Volstead Act is an important antitrust policy regarding farm gate economic power. The economic logic of Capper-Volstead, in an antitrust sense, is to allow producers to form organizations with countervailing power. The Sherman Act and additional antitrust legislation, such as the Robinson-Patman Act of 1936, seek to constrain exercise of market power by large firms. At the same time, Capper-Volstead seeks to encourage joint marketing among farmers as a countervailing activity.

The legislation influencing the nature of trade practices, together with public market information legislation, creates two meaningful sets of policies aimed at balancing economic power. The set of trade practice policies includes, but is not limited to, unfair trade regulation, prompt- and full- pay provisions, truth-in-trading requirements, and discriminatory practice regulation. Legislation in the U.S. includes the Packers and Stockyards Act of 1921, the Commodities Futures Trading

Commission Act of 1974, the Perishable Agricultural Commodities Act of 1930, the Agricultural Fair Practices Act of 1967, and the United States Warehouse Act in 1916.

From an economic standpoint, both market information and trade practice regulation are policies intended to equalize information in commodity markets. Collection of unbiased and statistically accurate market information promotes competition in the long-run. In general, public price reporting is justified on grounds of promoting competition, efficiency and fairness, as well as providing the federal government with information it needs for regulatory monitoring.

The U.S. Department of Agriculture (USDA) is internationally recognized and accepted to have the most reliable and timely market information systems in the world. It begins with the statistically reliable systems developed by the National Agriculture Statistics Service and the Outlook and Situation Board. Internationally, it relies on country data, weather reports, surveillance systems, and regular reports on production, supplies, and stocks supplied by Foreign Agriculture Service officers located in the embassies of countries around the world. Private intelligence is also provided by a number of companies.

Prices are meaningful only if they relate to products of identified homogeneous quality. This requires a grading system, which began early in the history of USDA and in some instances even before USDA was established. The broadest authorization for grading systems is provided by the 1946 Agricultural Marketing Act.

Public price reporting has become a controversial market information component as private reports have developed that directly compete with USDA market news reports. Sumner and Mueller (1987) show that private information is quickly embedded into USDA prices. Further complications have developed as markets become vertically coordinated (ownership integration or contractual) and rely on pricing formulas that include prices from either residual spot markets or from finished product markets. In thecase of eggs and meat, private price reporting evolved as the focus of the industry rather than USDA reports.

\footnotetext{
${ }^{1}$ Readers interested in more detail on these acts are urged to consult the Website of the Agricultural Law Center of the University of Arkansas [http://www.nationalaglawcenter.org/]. Details of each piece of legislation mentioned are provided along with recent case law interpretations. For a less technical treatment, see Breimyer (1976).
} 
Private reporting is acceptable to economic agents in the supply chain when the belief is that the private reports more accurately reflect market conditions compared to public reports. An issue is when contracts and integration account for a large share of total trades at a pricing point, the information value of the spot market is eroded. It is difficult to analyze when the information value of spot markets is no longer useful. The Livestock Mandatory Price Reporting Act of 1999 is one example of the policy reaction to this dilemma. This Act requires large meatpackers to report all livestock transaction prices to the Agricultural Marketing Service of USDA. The broader coverage mandated in the Act is in response to a persistent decline in the volumes traded through spot mar- kets. Dhuyvetter (2004) shows how the prices for segregated early-weaned pigs can be determined using market prices of inputs as a way to assist in price discovery when data is private.

The market structure of oligopsony at the farm gate has resulted, over many years, in legislation that attempts in various ways to countervail or redress the imbalance of market power. This has evolved into a complex of institutional and legislative aspects that serve to make commodity marketing an exclusive feature of agrifood supply. Agrifood supply chains in the U.S. economy exhibit an extensive array of institutions and legislation aimed at redressing the balance of market power.

\section{References}

1. Bailey D., Jones E., Dickinson D. L. (2002). Knowledge Management and Comparative International Strategies on Vertical Information Flow in the Global Food System. American Journal of Agricultural Economics84(5): 1337-1344.

2. Beddow J. M., Pardey P. G., Alston J. M. (2009). The Shifting Global Patterns of Agricultural Productivity. Choices24(4). http:// www.choicesmagazine.org/magazine/pdf/article_95.pdf(assessed October, 2011).

3. Black J. D. (1947). Guideposts in the Development of a Marketing Program. Journal of Farm Economics 29(3):616-631.

4. Breimyer H. F. (1976). Economics of the Product Markets ofAgriculture. Ames, Iowa: Iowa State Press.

5. Chandler A. D. (2005). Shaping the Industrial Century: The Remarkable Story of the Modern Chemical and Pharmaceutical Industries. Boston, MA: Harvard University Press.

6. Dorsey S., Boland M.A. (2009). Vertical Integration in the U.S. Food Economy, Journal of Agricultural and Applied Economics 41(3):585-598.

7. Enriquez J., Goldberg R.A. (2000). Transforming Life, Transforming Business: The Life- Science Revolution. Harvard Business Review 78(2): 94-104.

8. Federal Reserve Bank of Dallas. (2006). The Best of All Worlds: Globalizing the Knowledge Economy. Annual Report, Dallas, Texas.

9. Gardner B. L. (2002). American Agriculture in the Twentieth Century: How It Flourished and What It Cost. Cambridge, Mass.: Harvard University Press.

10. Goodhue R., Mohapatra S., Rausser G. (2010). Interactions between Incentive Instruments: Contracts and Quality in Processing Tomatoes. American Journal of Agricultural Economics 92(5): 1283-1293.

11. Hyson C. D. (1944). The Shift Towards Medium Staple Cotton. Journal of Farm Economics 26(2): 396-399.

12. James H. S., Klein P. G., Sykuta M. E. (2010). The Adoption, Diffusion, and Evolution of Organizational Form: Insights from the Agrifood Sector. Managerial and Decision Economics, CORI Working Paper No. 2007-01. (accessed October, 2011). http:// ssrn.com/abstract $=980301$.

13. Kinsey J. (2001). The New Food Economy: Consumers, Farms, Pharms, and Science. American Journal of Agricultural Economics 83(5):1113-30.

14. Kinsey J. R., Harrison W., Degeneffe D., Ferreira G., Shiratori S. (2009). Index of Consumer Confidence in the Safety of the United States Food System. American Journal of Agricultural Economics 91(5): 1470-1476.

15. MacDonald J., Korb M., Korb P. (2011). Agricultural Contracting Update: Contracts in 2008. Economic Information Bulletin Number 72, Economic Research Service, U.S. Department of Agriculture, Washington, D.C.

16. Martinez S. W., Reed A. (1996). From Farmers to Consumers: Vertical Coordination in the Food Industry. Agriculture Information Bulletin No. 720, U.S. Department of Agriculture, Economic Research Service.

17. Palma M. A., Ribera L. A., Bessler D., Paggi M., Knutson R. D. (2010). Potential Impacts of Foodborne Illness Incidences on Market Movements and Prices of Fresh Produce in the U.S. Journal of Agricultural and Applied Economics 42(4): 731-741.

18. Quan S., Zengu Y., Liu X. Yu, Liu Y. (2010). The Recovery of Consumer Purchasing Behavior after a Food Crisis: A Case Study of the Melamine Incident in China. Selected poster for the Agricultural and Applied Economics Association annual meeting, Denver, CO. http://purl.umn.edu/61042 (accessed May, 2011).

19. Sanchez D., Boland M. A., Sumner D. (2008). Sun-Maid Growers. Review of Agricultural Economics 30(2): 360-369.

20. Sanders M. E. 1998. Overview of Functional Foods: Emphasis on Probiotic Bacteria. International Dairy Journal 8(5/6):341347.

21. Seftel H. (1985). Government Regulation and the Rise of the California Fruit Industry: The Entrepreneurial Attack on Fruit Pests, 1880-1920.The Business History Review 59(3):369- 402.

22. Smith D., Sparks L. (2007). Temperature Controlled Supply Chains. In Food Supply Chain Management, edited by M. A. Bourlakis and P. W. H. Weightman, Chapter 12. Oxford, UK: Blackwell Publishing Ltd.

23. Southgate D. D., Graham D. H., Tweeten L. G. (2007). The World Food Economy. Malden, MA: Blackwell Publishing. 
24. Stigler G. J. (1945). The Cost of Subsistence. Journal of Farm Economics 27(2):303-314.

25. Sumner D., Mueller R. (1987). Are Harvest Forecasts News? USDA Announcements and Futures Markets Reactions. American Journal of Agricultural Economics 71(2):131-137.

26. Wittenberger K., Dohlman E. (2010). Peanut Outlook, Impacts of the 2008-09 Foodborne Illness Outbreak Linked to Salmonella in Peanuts. OCS-10a-01. Available online 31 May 2011.www.ers.usda.gov/Publications/OCS/2010/02Feb/OCS10A01/ ocs10a01.pdf

\section{Information about the authors}

Thomas L. Sporleder (Columbus, USA)и др.Professor of Agribusiness and Farm Income Enhancement Endowed Chair, Department of Agricultural, Environmental, and Development Economics, The Ohio State University (2120 Fyffe Road, Columbus, Ohio, 43210-1066, USA, e-mail: sporleder.1@osu.edu).

Michael A. Boland (St Paul, USA)и др.Koller Professor and Director of University of Minnesota, Food Industry Center (317D Classroom Office Building, 1994 Buford Avenue, St Paul, Minnesota, 55108, USA, e-mail:boland@umn.edu). 